\title{
Race and Gender Mentor-Protégé Pairings of Resident Assistants: An Exploration on Leadership Capacity
}

\author{
Dr. Sherry L. Early \\ Assistant Professor, Leadership Studies \\ Marshall University
}

\begin{abstract}
The leadership capacity of resident assistants can be impacted by many experiences, including involvement in mentoring relationships. The purpose of this study was to examine if and how resident assistants' leadership capacities are influenced by participating in mentoring relationships. Additionally, mentor-protégé race and gender pairings were explored. An adapted version of Astin's Inputs-Environments-Outcomes college impact model was used as the conceptual framework; the Social Change Model of Leadership was used as the theoretical framework. Overall findings included that resident assistants with a race match or gender match did not exhibit significantly higher leadership capacities than those who did not. I also included implications for practice and future recommendations.
\end{abstract}

\section{Introduction}

Within mentoring literature, the primary focus has been on mentoring functions, cultivating mentor/protégé relationships, and the desired behaviors of mentors (Swap, Leonard, Shields, \& Abrams, 2001). Mentors as teachers, educators, or managers have been charged with building the skill sets of their protégés; this process provides both socialization (shared experiences or culture) and internalization (learning by doing) through a more formalized learning lens (Swap et al., 2001). This view of the mentoring process takes into account that there are many types of mentors (faculty, career, student affairs, senior faculty, peer) and protégés (students, junior faculty, organizational members, employees, peers) who engage in formal and informal capacities with both task and relationship outcomes. Mentoring is a mutual exchange and relational in nature. This notion opens up a broader interpretation of who can mentor and who can serve as a protégé (Campbell, Smith, Dugan, \& Komives, 2012; Kram, 1983).

Mentor-Protégé Demographic Factors. Mentoring relationships do not occur in a vacuum; they are influenced by intergroup power relationships and can be very complex (Ragins, 1997). Demographic factors including race and gender should be taken into consideration in mentoring relationships and exchanges: "Competent mentors are sensitive to issues of sex, gender socialization, gender identity, and sexual orientation but they avoid assuming that these factors alone predict important mentoring needs, relational styles, or professional concerns" (Johnson, 2006, p. 165). Mentors should also be mindful of creating safe and inclusive environments for their protégés. Though potential protégés may express a preference for a mentor of the same race, research indicates cross-race mentorships can be just as helpful, valuable, and satisfying as same-race mentorships: 
Diversified mentoring relationships are composed of mentors and protégés who differ on one or more group memberships associated with power in organizations...diversified mentoring relationships are not intrinsically better or worse than homogeneous relationships; each has costs and benefits. (Ragins, 1997, p. 489)

The key takeaway is that the mentor-protégé exchange is mutual and relational regardless of any demographic similarities or differences. The focus of the present study is on resident assistants and their self-identified most significant mentors' race and genders.

Resident Assistants and Socially Responsible Leadership. The use of student staff in housing began in the Colonial colleges (Winston \& Fitch, 1993). Because behavior problems stemmed from young men who lived in close quarters with little area to socialize, American colonial faculty had to assume the parental, authoritative role of providing "custodial care," serving in loco parentis in order to maintain acceptable conduct (Winston, Ullom, \& Werring, 1984). As residence life became more of an established functional area, a more holistic and less punitive approach was employed when working with students in the residence halls (Blimling \& Miltenberger, 1984), which resulted in the need for paraprofessionals to live with students. Paraprofessional staff allowed professional staff time to address bigger concerns: fostering developmental academic and social interactions through educational programs (Ender, 1984; Kennedy, 2009). This shift in responsibility provided growth and leadership opportunities for the paraprofessional staff members.

The study of leadership can be traced all the way back to Aristotle (Northouse, 2010). How leaders have been viewed has changed significantly over the centuries, and an awareness of the philosophical evolution of leadership is necessary to understand major epistemological frames. Leadership theory has evolved from a positivist paradigm of universal truths and single, right ways to a naturalistic, socially-constructed view (Dugan \& Komives, 2010): "The evolution of leadership theory reflects a complex movement from leader-centric, management-oriented, and individual achievement-focused approaches to those characterized by social responsibility, developmental concern, and process orientations" (Dugan, 2011, p. 53). This movement distinguished between industrial and postindustrial theoretical paradigms, and the emphasis has evolved from focusing on the leader to cultivating leadership development to benefit society.

The Social Change Model of leadership (SCM) provides a framework for individuals and groups to engage in leadership and learn from one another to enact change through a nonhierarchical model rooted in a postindustrial framework (Higher Education Research Institute [HERI], 1996; Komives, Lucas, \& McMahon 2007; Skendall, 2012). Starting in 1996, this model was widely distributed throughout the higher education community (Astin \& Astin, 2000; Cilente, 2009; HERI, 1996) as a way to represent leadership process rather than leadership position.

Research has been conducted on mentoring and socially responsible leadership and leadership capacity, but leadership efficacy has not been addressed; few studies have focused on the leadership capacities and mentoring experiences of resident assistants. None have included consideration of the demographics of the mentor-protégé pairings and of the impact of mentoring outcomes on resident assistants' leadership capacities. To address this problem, the purpose of 
this study was to examine how resident assistants' leadership capacities (socially responsible leadership and leadership efficacy) are influenced by being involved in mentoring relationships (e.g., mentoring for personal development and/or mentoring for leadership empowerment). The research question was:

Does the relationship between mentoring relationships and leadership capacity differ based on the race and gender match of the mentor-protégé pairing, after accounting for control measures such as pre-college activities, sexual orientation, grade point average, parental income, and major?

The Instrument. The theoretical framework of the Multi-Institutional Study of Leadership (MSL) is the Social Change Model of Leadership (SCM), which views leadership as a process, not a position. The SCM is values-based and includes "equity, social justice, selfknowledge, personal empowerment, collaboration, citizenship, and service" (HERI, 1996, p. 18), and it underscores personal and interpersonal dimensions of leadership (HERI, 1996; Tyree, 1998). It has two core principles. First, it is predicated on increasing students' levels of selfknowledge and capacity to collaborate with others. Second, leadership is tied to societal responsibility and demonstrated by creating positive change for the common good (Dugan \& Komives, 2010; HERI, 1996). The Social Change Model has three interrelated perspectives: the individual, the group, and society/community (see Figure 1).

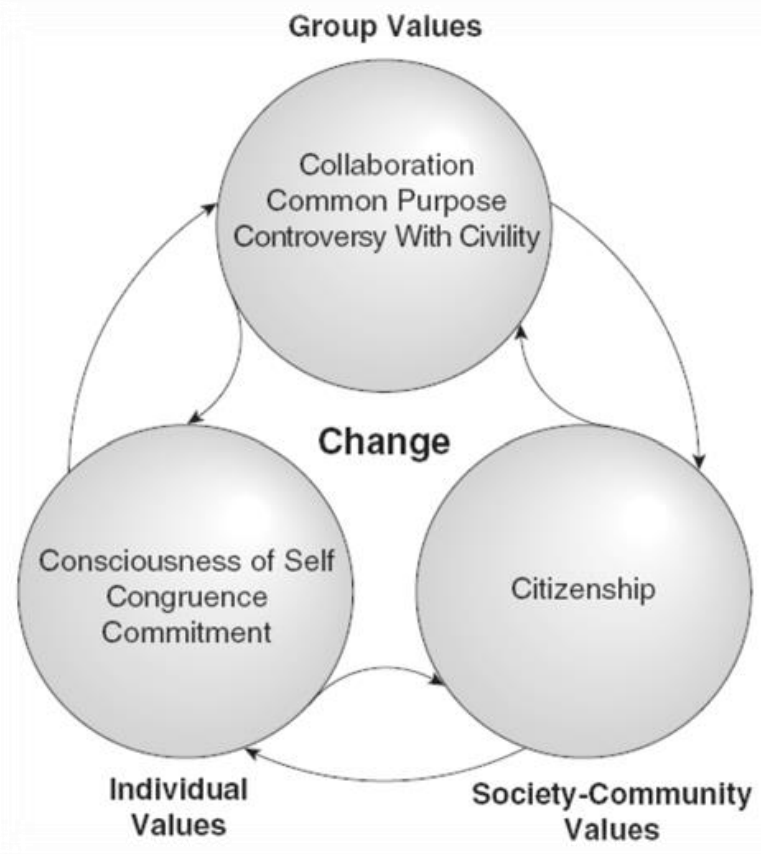

Figure 1. The Social Change Model of Leadership Development Source: Komives, S. R., \& Dugan, J. P. (2011a). Contemporary leadership theories. In S. R. Komives, J. P. Dugan, J. E. Owen, C. Slack, W. Wagner, \& Associates (Eds.), The handbook for student leadership development (2nd ed.). San Francisco, CA: Jossey-Bass. 
The Multi-Institutional Study of Leadership has been used to examine educational outcomes of the collegiate environment since 2006. The Social Change Model is the theoretical framework for the MSL study, while Astin's Input-Environment-Outcome (I-E-O) model serves as the conceptual framework (see Figure 2). The MSL Survey has more than 400 variables, scales, and composite measures (Multi-Institutional Study of Leadership [MSL], n.d.) and used the 71-item Socially Responsible Leadership Scale (SRLS) as the core scale. Data collection was conducted from January 2009 through April 2009; each participating institution selected a threeweek period most conducive to their academic calendar for students to receive the survey electronically. Data collection overview information can be retrieved from http://leadershipstudy.net/design/data-collection-methods
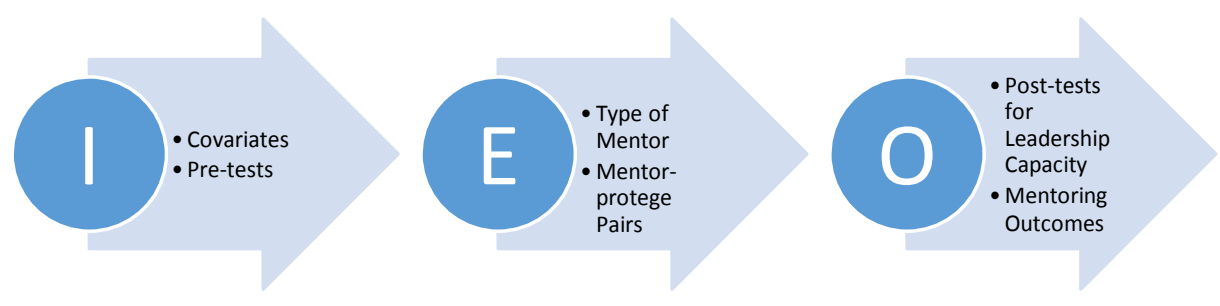

Figure 2. Astin's I-E-O Model with Variables of Interest Figure

Source: Author. (2014). An Examination of Mentoring Relationships and Leadership Capacity in Resident Assistants. (Electronic Thesis or Dissertation). Retrieved from The Multi-Institutional Study of Leadership's 2009 sample consisted of 35\% $(n=118,733)$ of the 337,482 students who were electronically invited to participate; the resident assistant sub-sample size was 6,006. Resident assistants were asked if they had ever been mentored, and $95.6 \%$ indicated they had been mentored at least once $(n=5,741)$ while $4.4 \%$ indicated they had never been mentored $(n=$ 265). Multiple regression analysis was conducted to explore mean differences across the dependent variables (eight SCM leadership constructs, socially responsible leadership, and leadership efficacy). IBM SPSS Statistics 22 software was used to conduct the analyses.

Analyses and Results. Through independent sample $t$-tests and regression the researcher compared group mean scores of race/gender match and cross race/gender pairs of resident assistants on the Social Change Model individual, group, societal, and change constructs to better understand socially responsible leadership. Socially responsible leadership is the omnibus of all eight SCM constructs in a single variable. A more advanced understanding of socially responsible leadership and leadership efficacy provides a more thorough understanding of the study's dependent variable, leadership capacity. The research question was analyzed in a singleblock model including covariates (pre-college activities, major, sexual orientation, citizenship/generational status, parents' education level, parents' income, grade point average) and the socially responsible leadership and leadership efficacy pre-tests along with a researchquestion-specific key predictor. 
With larger sample sizes there could be statistical significance, but not practical significance; therefore, it is important to examine effect size in addition to significance. The effect size measures the size of the difference between two groups and is a measure of the practical significance of the difference (Coe, 2002). The effect size or Cohen's $d$ is the difference between the means divided by the standard deviation. Two groups' means should differ by at least .2 standard deviations or more. Cohen (1988) stated $d=.2$ for a small effect size, $d=.5$ for a medium effect, and $d=.8$ for a large effect. For all variables the effect sizes are not large; however, the group means differ by at least .2 standard deviations, and the differences ranged from small to medium.

To address the research question, I examined the Social Change Model constructs. A comparison of independent sample $t$-tests and regression analyses were conducted. Ragins (1997) identified an important research conundrum, arguing that studies on race and mentoring relationships have inconsistent findings because confounding variables had not been used as a measure of control. The pre-tests for socially responsible leadership and leadership efficacy and the gender match and race match variables were also included in the model. It was hypothesized same-gender pairs would score significantly higher on socially responsible leadership based on MSL 2006 findings.

Of the mentored RA sample 3,289 mentors were reported as Caucasian/White of the 3,984 reported mentor races. The highest percentage of same-race mentor-protégé pairings in the RA sample were White-White $(82.56 \%)$. See Table 1 for a more complete mentorprotégé racial pairing profile.

Table 1

Most Significant Mentor-Protégé Racial Profile

\begin{tabular}{lccccc} 
Protégé Race & $\mathrm{n}$ & $\%$ & $\begin{array}{c}\text { Race of Most } \\
\text { Significant Mentor }\end{array}$ & $\mathrm{n}$ & $\%$ \\
\hline Caucasian/White & 4253 & 72.50 & Caucasian/White & 3289 & 82.56 \\
Middle Eastern & 129 & 02.20 & Caucasian/White & 49 & 01.23 \\
$\begin{array}{l}\text { African American/ } \\
\text { Black }\end{array}$ & 583 & 10.00 & African American/ & 273 & 06.85 \\
$\begin{array}{l}\text { Native American } \\
\text { Msian American }\end{array}$ & 83 & 01.40 & $\begin{array}{c}\text { Asian American/ } \\
\text { Pacific Islander }\end{array}$ & 33 & 00.83 \\
$\begin{array}{l}\text { Pacific Islander } \\
\text { Latino/Hispanic }\end{array}$ & 359 & 06.20 & $\begin{array}{c}\text { Asian American/ } \\
\text { Pacific Islander }\end{array}$ & 182 & 04.57 \\
Multiracial & 263 & 04.50 & Caucasian/White & 99 & 02.48 \\
\hline
\end{tabular}


The resident assistant (RA) sample reported 5,420 genders for their most significant mentors. The mentor-protégé pairings for most significant mentor had the highest frequency for women-women pairs $(n=2,143)$. For the full most significant mentor gender profile, see Table 2 below.

Table 2 Most Significant Mentor-Protégé Gender Profile

\begin{tabular}{rrrrrr} 
Protégé Gender $(\mathrm{n})$ & $\mathrm{n}$ & $\%$ & Mentor Gender & $\mathrm{n}$ & $\%$ \\
\hline & & & & & \\
Women & 2831 & 52.23 & Women & 2146 & 58.94 \\
Transgender & 59 & 01.09 & Transgender & 25 & 00.69 \\
Men & 2530 & 46.68 & Men & 1470 & 40.37 \\
\hline
\end{tabular}

I examined mentoring outcomes and the social change model constructs, and leadership capacity by examining group means through independent samples $t$-tests. It was hypothesized same-race and same-gender mentor-protégé pairings will score highest on leadership capacity. Before examining the pairs, I chose to examine gender and racial characteristics. I compared mentoring outcomes by gender and women scored significantly higher on both mentoring outcomes. I also compared the social change model (SCM) individual (congruence, consciousness of self, commitment), group values (collaboration, common purpose, controversy with civility), societal constructs (citizenship), and outcome value (change). Women scored significantly higher on all SCM constructs and change. Finally, women RAs scored significantly higher on socially responsible leadership and leadership efficacy. I further examined the dependent variables by conducting an independent samples $t$-test for gender including women and men. Transgender RAs were excluded because they were few in number and their scores were much lower than the other genders thereby drastically altering the $t$-values in comparison to men and women RAs.

I explored mentoring outcomes, social change model constructs, and leadership capacity by examining group means to further examine the differences between the groups. I compared mentoring outcomes by race and African American/Black resident assistants scored significantly higher on both mentoring outcomes. I compared the social change model (SCM) individual (congruence, consciousness of self, commitment), group values (collaboration, common purpose, controversy with civility), societal constructs (citizenship), and outcome value (change). African American/Black RAs scored significantly higher on all SCM individual and societal values and change. Multiracial RAs scored significantly higher on group values. Finally, African American/Black RAs scored significantly higher on socially responsible leadership and leadership efficacy.

The categorical variables were dummy coded with the largest number and all others. When examining the dummy variables, White RAs scored significantly higher on mentoring outcomes, SCM individual and group constructs, and leadership capacity. All others scored significantly higher on the societal SCM value and change. I also examined gender dummy 
variable group means and women RAs scored significantly on all educational outcomes except socially responsible leadership (SRL); all others scored significantly higher on SRL and none of the variables were significant to the $95 \%$ confidence level.

As an environmental predictor of leadership capacity, I compared same and cross-race mentor-protégé pairs. Same-race mentor-protégé pairs reported significantly higher scores on mentoring for leadership empowerment than cross-race mentor-protégé pairs $(M=4.26$ compared to $M=4.20), \mathrm{p}>.05$. Although the means are higher for same-race mentor-protégé pairs, the finding was not statistically significant. Same-gender mentor-protégé pairs reported lower levels of mentoring for leadership empowerment than cross-gender mentor-protégé pairs $(M=3.99$ compared to $M=4.00), \mathrm{p}>.05$.

To test the hypothesis that same-race and same-gender mentor-protégé pairs would score higher on the dependent variable, leadership capacity, I compared the means of RAs who identified mentors of the same race $(n=3,899)$ to RAs who identified mentors of a different race $(\mathrm{n}=1,502)$. Same-race mentor-protégé pairs reported higher levels of socially responsible leadership scores than cross-race mentor-protégé pairs $(M=4.05$ compared to $M=4.04), \mathrm{p}>.05$. Same-gender mentor-protégé pairs reported lower levels of socially responsible leadershipscores than cross-gender mentor-protégé pairs $(M=4.04$ compared to $M=4.06), \mathrm{p}>.05$. Same-race mentor-protégé pairs scored higher on leadership efficacy scores than cross-race mentor-protégé pairs $(M=3.29$ compared to $M=3.26)$, p>.05. Same-gender mentor-protégé pairs reported lower levels of leadership efficacy scores than cross-gender mentor-protégé pairs $(M=3.28$ compared to $M=3.29), \mathrm{p}>.05$.

\section{Mentoring Outcomes as a Predictor of Leadership Capacity}

I further examined the mentoring outcomes as an environmental predictor of leadership capacity. The results of the regression in Model 1 indicated three predictors explained $01.7 \%$ of the variance $\left(R^{2}=.017, F(7,2637)=6.487, p<.0001\right)$. It was found that major $(\beta=-.073, p<.0001)$, pre-college activities $(\beta=.079, \mathrm{p}<.0001)$, and citizenship status $(\beta=.-066, \mathrm{p}<.01)$ significantly predicted mentoring for leadership empowerment. These were not strong predictors because $98.0 \%$ of the variance is not explained. Pre-college activities emerged once again as the only statistically significant predictor that was positively correlated. When the pre-tests for socially responsible leadership and leadership efficacy were included in Model 2 the results of the regression indicated the two predictors explained $04.90 \%$ of the variance $\left(\mathrm{R}^{2}=.049\right.$, $\mathrm{F}(9,2635)=15.050, \mathrm{p}<.0001)$. It was found the pre-test for socially responsible leadership $(\beta=.135, \mathrm{p}<.0001)$ and the pre-test for leadership efficacy $(\beta=.078, \mathrm{p}<.0001)$ predicted mentoring for leadership empowerment. Both pre-tests were significant and positively correlated however more than $95.0 \%$ of the variance was not accounted for. When the variable mentors and protégé pairs of the same race was included in Model 3, the results of the regression indicated that the predictor explained $05.10 \%$ of the variance $\left(\mathrm{R}^{2}=.051, \mathrm{~F}(7,2630)=06.528, \mathrm{p}<.0001\right)$. It was found same-race mentor-protégé pairs $(\beta=.039, \mathrm{p}<.05)$ predicted mentoring for leadership empowerment. Less than $94.0 \%$ of the variance was accounted for in Model 3 so mentoring was a weak, but statistically significant and positively correlated predictor of leadership empowerment. 
The results of the regression in Model 1 indicated that four predictors explained $02.00 \%$ of the variance $\left(\mathrm{R}^{2}=.020, \mathrm{~F}(7,2635)=7.699, \mathrm{p}<.0001\right)$. It was found that major $(\beta=-.050, \mathrm{p}<.05)$, pre-college activities $(\beta=.072, \mathrm{p}<.0001)$, sexual orientation $(\beta=-.052, \mathrm{p}<.05)$, and citizenship status $(\beta=.-086, p<.0001)$ significantly predicted mentoring for personal development. The predictors were very weak and $98.0 \%$ of the variance was not accounted for and pre-college activities were the only predictor that was positively correlated. When the pre-tests for socially responsible leadership and leadership efficacy were included in Model 2 the results of the regression indicated that the two predictors explained $07.80 \%$ of the variance $\left(\mathrm{R}^{2}=.078\right.$, $\mathrm{F}(9,2633)=24.611, \mathrm{p}<.0001)$. It was found that the pre-test for socially responsible leadership $(\beta=.211, p<.0001)$ and the pre-test for leadership efficacy $(\beta=.062, p<.01)$ predicted mentoring for personal development.

Although the pre-tests were significant and positively correlated, more than $92.0 \%$ of the variance was not explained. When the variable that included mentor- protégé pairs of the same gender was included in Model 3, the results of the regression indicated that the predictor explained $07.90 \%$ of the variance $\left(\mathrm{R}^{2}=.079, \mathrm{~F}(10,2632)=8.904, \mathrm{p}<.0001\right)$. It was found that same-gender mentor-protégé pairs $(\beta=-.032, \mathrm{p}>.05)$ did not predict mentoring for personal development. The same-gender predictor was negatively correlated with nearly $92.0 \%$ of the variance unaccounted for and the unstandardized coefficient was not statistically significant.

The dependent variable, leadership capacity (socially responsible leadership and leadership efficacy) was examined through regression analysis. The results in Model 1 indicated that five predictors explained $02.50 \%$ of the variance $\left(R^{2}=.025, F(7,5388)=19.453, p<.0001\right)$ for socially responsible leadership (SRL). It was found that grade point average $(\beta=-.074, p<.0001)$, major $(\beta=-.058, p<.0001)$, pre-college activities $(\beta=.069, \mathrm{p}<.0001)$, citizenship status $(\beta=-.093$, $\mathrm{p}<.0001)$, and sexual orientation $(\beta=-.036, \mathrm{p}<.05)$ significantly predicted socially responsible leadership. The predictors were weak and over $97.0 \%$ of the variance was not explained and only pre-college activities were positively correlated with SRL. When the pre-tests for socially responsible leadership and leadership efficacy were included in Model 2, the results of the regression indicated that the two predictors explained $27.90 \%$ of the variance $\left(\mathrm{R}^{2}=.279\right.$, $\mathrm{F}(9,30.748)=232.018, \mathrm{p}<.0001)$. It was found the pre-test for socially responsible leadership $(\beta=.450, p<.0001)$ and the pre-test for leadership efficacy $(\beta=.075, p<.0001)$ predicted socially responsible leadership. The increased percentage of variance explained and much larger $F$ value in addition to both pre-tests being positively correlated made them stronger predictors. When the same gender mentor-protégé variable was included in Model 3, the results of the regression indicated that the predictor explained $28.00 \%$ of the variance $\left(\mathrm{R}^{2}=.280, \mathrm{~F}(10,5385)=209.301\right.$, $\mathrm{p}<.0001)$. The same-gender predictor was negatively correlated with $72.0 \%$ of the variance was not explained and the unstandardized coefficient was not statistically significant. Therefore, same-gender mentor-protégé pairs $(\beta=-.023, \mathrm{p}>.05)$ did not predict socially responsible leadership

With respect to leadership efficacy, the results of the regression in Model 1 indicated that five predictors explained $01.90 \%$ of the variance $\left(\mathrm{R}^{2}=.019, \mathrm{~F}(7,5388)=14.515, \mathrm{p}<.0001\right)$. It was found grade point average $(\beta=-037, p<.05)$, major $(\beta=-035, p<.05)$, pre-college activities $(\beta=.107, \mathrm{p}<.0001)$, citizenship status $(\beta=-.058, \mathrm{p}<.0001)$, and parents' education $(\beta=-.028$, $\mathrm{p}<.05)$, and parents' education $(\beta=-.027, \mathrm{p}<.05)$ significantly predicted leadership efficacy. More 
than $98.0 \%$ of the variance was not explained, pre-college activities were the only predictor that was positively correlated, and the unstandardized coefficient was not statistically significant. When the pre-tests for socially responsible leadership and leadership efficacy were included in Model 2, the results of the regression indicated that the two predictors explained $20.60 \%$ of the variance $\left(\mathrm{R}^{2}=.206, \mathrm{~F}(9,5386)=155.250, \mathrm{p}<.0001\right)$. I found the pre-test for socially responsible leadership $(\beta=.186, \mathrm{p}<.0001)$ and the pre-test for leadership efficacy $(\beta=.331, \mathrm{p}<.0001)$ predicted leadership efficacy. Nearly $80.00 \%$ of the variance was not explained, however both pre-tests were positively correlated and the unstandardized coefficient was statistically significant. Therefore, the pre-tests were good predictors of leadership efficacy. When the same gender mentor-protégé variable was included in Model 3, the results of the regression indicated the predictor explained $20.60 \%$ of the variance $\left(\mathrm{R}^{2}=.206, \mathrm{~F}(10,5385)=139.781, \mathrm{p}<.0001\right)$. Samegender mentor-protégé pairs $(\beta=-.010, \mathrm{p}>.05)$ did not predict leadership efficacy. Although $20.60 \%$ of the variance was explained and the pre-tests were positively correlated in Model 2, the same-gender variable was negatively correlated and the unstandardized coefficient was not statistically significant in Model 3. The mentor-protégé race and gender comparison of means, standard deviations, and $t$-values on educational outcomes can be found in Table 3 below.

Table 3

Resident Assistant Mentor-Protégé Race and Gender Comparison of Means, Standard Deviations, and $t$-Values on Educational Outcomes

\begin{tabular}{|c|c|c|c|c|c|c|c|}
\hline Outcome & Race & $M$ & $S D$ & Gender & $M$ & $S D$ & t-Value \\
\hline \multirow{2}{*}{$\begin{array}{l}\text { Mentoring for } \\
\text { personal } \\
\text { development }\end{array}$} & Same-race & 4.26 & .63 & Same-gender & 4.23 & .66 & \\
\hline & Cross-race & 4.20 & .71 & Cross-gender & 4.27 & .65 & 1.502 \\
\hline \multirow{2}{*}{$\begin{array}{l}\text { Mentoring for } \\
\text { leadership } \\
\text { empowerment }\end{array}$} & Same-race & 4.03 & .84 & Same-gender & 3.99 & .87 & \\
\hline & Cross-race & 3.92 & .92 & Cross-gender & 4.00 & .85 & 0.152 \\
\hline \multirow{2}{*}{$\begin{array}{l}\text { Socially } \\
\text { responsible } \\
\text { leadership }\end{array}$} & Same-race & 4.05 & .42 & Same-gender & 4.04 & .43 & \\
\hline & Cross-race & 4.04 & .46 & Cross-gender & 4.06 & .42 & 1.557 \\
\hline \multirow{2}{*}{$\begin{array}{l}\text { Leadership } \\
\text { efficacy }\end{array}$} & Same-race & 3.29 & .59 & Same-gender & 3.28 & .59 & \\
\hline & Cross-race & 3.26 & .62 & Cross-gender & 3.29 & .61 & 0.621 \\
\hline
\end{tabular}

Overall, the race and gender mentor-protégé findings were that pre-college activities served as the strongest positively correlated predictor of leadership capacity (socially responsible leadership and leadership efficacy) in Model 1 for mentor-protégé race and gender pairings. The pre-tests explained a larger percentage of the variance in Model 2 and were positively correlated and statistically significant for mentor-protégé race and gender pairings. In Model 3, of the social change model constructs, statistical significance was found for same-race mentor-protégé 
pairs on change. Of the educational outcomes, statistical significance was found for same-race mentor-protégé pairs on mentoring for leadership empowerment. With respect to the social change model constructs, statistical significance was found for same-gender mentor-protégé pairs on group and the societal constructs. Of the educational outcomes, no statistical significance was found for same-gender mentor-protégé pairs. It was determined same-race and same-gender mentor-protégé pairs do not differ significantly from cross-race and crossgender mentor-protégé pairs on leadership capacity (socially responsible leadership and leadership efficacy).

Disaggregated findings included women RAs scored higher on leadership capacity than any other gender and African American/Black RAs scored higher on leadership capacity than any other race. Same-race mentor-protégé pairs had higher means on leadership capacity. Statistical significance was found for same-race mentor-protégé pairs on mentoring for leadership empowerment. With respect to the social change model constructs, statistical significance was found for same-gender mentor-protégé pairs on group and the societal constructs. Of the educational outcomes, no statistical significance was found for same-gender mentor-protégé pairs. Finally, it was determined that same-race and same-gender mentorprotégé pairs do not differ significantly from cross-race and cross-gender mentor-protégé pairs on leadership capacity (socially responsible leadership and leadership efficacy). Through regression analysis, race match and gender match for mentor-protégé pairings did not predict leadership capacity (socially responsible leadership and leadership efficacy). Therefore, gender match and race match mentor-protégé pairs did not differ from cross-gender and cross-race mentor-protégé pairs.

Implications for Practice. The findings from this study can equip educators and potential mentors with evidence-based information on the benefits of cultivating the leadership capacities in resident assistants. These results also address both practical and scholarly implications often missing in research findings. The student affairs practitioners (hall directors, student organization advisors, leadership coordinators, fraternity and sorority advisors) resident assistants learn from outside of the classroom and the faculty they learn from inside the classroom can have a direct, positive influence on RAs' leadership capacities.

This study offers not only a unique contribution to the MSL research agenda, but also provides insights to new constituent audiences: housing and residence life administrators, fraternity and sorority advisors, leadership and service coordinators and more. Student success and collaboration with academic affairs are priorities at most institutions of higher education; this research could be helpful to hall directors and faculty associated with living-learning communities and advisors of residential organizations who may serve as mentors to resident assistants. Findings from this study suggest even one quality mentoring encounter is beneficial for RAs. To provide an overall analysis, mentored RAs scored significantly higher than nonmentored RAs on each value of the Social Change Model, socially responsible leadership, and leadership efficacy. Additionally, RAs mentored by student affairs professionals scored higher than did those with any other type of significant mentor on both mentoring outcomes and leadership efficacy. Due to the nature of the profession, student affairs professionals, including housing and residence life administrators, have various opportunities to establish mentoring relationships with RAs and to help build their confidence in their abilities as leaders. Although 
there were some benefits to the type of mentor and/or the gender and race match mentor-protégé pairings, the main finding was that any type of mentoring relationship is crucial in the development of resident assistants' leadership capacities.

Faculty and administrators should strive to interact frequently in both informal and formal capacities with resident assistants because there is a measurable benefit. Findings from this study supported the assumption that gender match and race match mentor-protégé pairs do not significantly differ from cross-race and cross-gender mentor-protégé pairs on leadership capacity. This finding is very useful because there may be a limited number of racially diverse or non-binary gendered backgrounds for potential protégés. Therefore, being mentored by someone of a different race or gender is not disadvantageous; what is most important is that the resident assistant has been mentored. Any type of mentor including housing and residence life administrators on a college or university campus can impact a resident assistant's leadership capacity.

Institutions of higher education can also benefit from mentoring relationships with resident assistants. Stakeholders in higher education (administrators, faculty, students, alumni, donors) acknowledge matriculation, retention, and graduation of students as a priority (Tinto, 2006). Students who aid in these efforts are valuable; how they are developed and mentored is worthy of study. Therefore, those who mentor resident assistants not only benefit the protégé but also others they encounter. This may increase retention efforts and student satisfaction with their collegiate experiences (Astin, 1984).

Evidence-Based Research. Many leadership researchers have utilized the entire MSL sample, yet few have designed studies with sub-samples. I designed this study so it could be replicated for different sub-samples or student group types (orientation leaders, fraternity/sorority members, student organization members) from the MSL data. In addition, this study utilized researcher-selected covariates of interest, though other researchers may choose to use the data in another way. For example, they may want to explore the most significant type of mentor or mentor-protégé race and gender pairings and students' major - such as Science, Technology, Engineering, and Math (STEM) majors - as opposed to using major as a measure of control. This would be particularly interesting for majors with a predominance of one gender (Engineering) or race (African American Studies). Finally, other researchers may choose different covariates for predictive purposes to combat confounding factors.

Mentor-Protégé Gender Pairings and Leadership Capacity. Dugan (2006) explored the SCM and leadership development among college men and women in a Journal of College Student Development research in brief. Mean scores revealed women scored higher on all eight SCM values. Follow-up analysis indicated significance on six of the eight scales. Dugan argued colleges should strive to close performance gaps between men and women and conduct more research linked to the SCM and predictors from the collegiate environment that contribute to students' development. In this study, I found women scored significantly higher across all constructs of the social change model socially responsible leadership, and leadership efficacy. In the years since Dugan's 2006 publication, women have consistently outscored men on socially 
responsible leadership; in this study women scored slightly statistically higher than men on leadership efficacy, a contradiction to the 2006 findings.

Komives (1991) conducted a study examining the relationship of same- and cross-gender work pairs of resident assistants (RAs) and their supervisors, hall directors (HDs) on employee outcome measures (e.g., HD's vision, motivation to do extra effort for their RA role, satisfaction with their HD). The majority of the supervisors (58\%) and RAs (55\%) were women. One third of the supervisor-supervisee pairs were women-women. Komives found no differences between gender of the supervisor and supervisee on the dependent variables. Komives' findings were consistent with previous studies including Bartol and Wortman (1976) and Stitt, Schmidt, Price, and Kipnis (1983). However, women RAs reported slightly higher levels of satisfaction when their HDs were men, but the differences were not significant. This study found cross-gender mentor-protégé pairs have statistically significant higher mean scores and that men and women did not differ significantly on leadership capacity.

Young, Cady, and Foxon (2006) concluded gender similarity and interpersonal skills were relevant for women protégés' perceptions of and satisfaction with their women mentors, however, they did not explore cross-gender mentoring relationships. Ensher and Murphy (1997) found gender similarity to be less salient than race similarity in mentoring relationships. According to Johnson (2007), mentoring literature findings revealed men and women were mentored at equivalent rates and mentoring functions were consistent across sex; cross-sex and same-sex mentorships have been deemed equally successful. Ragins (1997) concluded crossrace mentorships can be as helpful, valuable, and satisfying as same-race mentorships. Based on findings from this study, I suggest there is equality across genders and a commitment to gender efficacy due to the success of cross-gender mentor-protégé pairs. Independent $t$-tests revealed women and men did not differ significantly on leadership capacity. Regression analyses determined the race and gender mentor-protégé pairings did not predict leadership capacity. The findings on gender and race mentor-protégé pairings and leadership capacity further validate that resident assistants who participate in mentoring relationships, regardless of the mentor-protégé race and gender matches, will demonstrate significantly higher leadership capacities than resident assistants who do not.

Mentor-Protégé Race Pairings Leadership Capacity. Ragins (1997) identified an important research conundrum, arguing research on race and mentoring relationships have inconsistent findings because confounding variables have not been used as a measure of control. This study implemented seven covariates as measures of control and found statistically significant mean differences for both mentoring outcomes and leadership capacity when examining mentor-protégé gender pairings. I found the race and gender mentor-protégépairings did not predict leadership capacity. Perhaps this is due to the resident assistants' views on mentorship with respect to gender and race and disproportionate number of diverse mentors. Dugan, Kodama, and Gebhardt (2012) used the 2009 MSL data to examine the influences of race on SRL through collective racial esteem (CRE). "CRE examines an individual's self-concept related to membership in a broader racial group and may be used as a correlate of racial identity in assessing the impact of race in quantitative research" (Dugan et al., 2008, p. 174). They found in quantitative research, racial categories had limited meaning for understanding the influences of race on leadership; thus, explaining contradictory findings from qualitative and quantitative 
studies. They argued disaggregation of analyses by racial group identified unique predicators of SRL along with unique CRE influences.

If social justice is truly a critical component of leadership development, if leadership is the learnable capacity scholars suggest it is, and if higher education intends to fulfill its societal commitment to prepare the next generation of citizen leaders, then the gap in understanding the influences of race on leadership development needs to be diminished. (Dugan et al., 2012, p. 186).

They also found socio-cultural conversations with peers emerged as the strongest predictor and most potent environmental influence on SRL. Further, developing an internally validated racial self-concept was significant for leadership capacity. High CRE among minoritized students may correlate with increased resilience, rejection of stereotype or threat and/or navigating hostile climates (Dugan et al., 2012). For this study, when I disaggregated dummy variables for each racial category, African-American/Black RAs scored highest on leadership capacity and mentoring outcomes. However, when I collapsed dummy variable consisting of Caucasian/White and all other races, Caucasian/White RAs had the highest leadership capacity and mentoring outcome scores. This further substantiates Dugan et al.'s argument that the disaggregation of analyses by racial group can identify unique predicators on capacity.

Limitations. There are limitations associated with this study related to the MSL's crosssectional design. Astin's Input-Environment-Outcome model, the conceptual framework for the study, and the chosen covariates took pre-college experiences into account to examine the environment's influence on the educational outcomes. However, the study was not experimental research; therefore, cause and effect could not be determined. The use of retrospective questioning techniques in cross-sectional studies required students to reflect on their pre-college experiences and to self-report them; this is appropriate for this study because comparisons across institutions are not the intent. Instead, measurement of educational outcomes associated with individual students' leadership capacities is the intent. Although the MSL has data from many institutions and researchers can control for institutional selectivity and size, students' retrospective self-reported responses are unique to them and their collegiate experiences. Further, between-college effects tend to be poor predictors of student outcomes once one controls for precollege activities (Pascarella \& Terenzini, 2005).

Admittedly, resident assistants' roles and responsibilities may be relatively similar between institutions; however, the expectations of residence life and housing departments, hiring and evaluation processes, and training of these paraprofessionals may differ drastically. The mentor-protégé relationships and experiences were reported from the protégé perspective only. Finally, the mentoring that is being self-reported could have occurred one time; therefore, it cannot be assumed that there is a true mentoring "relationship" as opposed to a single mentoring encounter. Respondents reported the most significant type of mentor and their mentor's gender and race, yet there is no further context related to the mentoring relationship (duration of the mentoring relationship, including additional mentor demographics). This information could provide more insight into the mentor-protégé dynamics.

Conclusion. In this study I examined mentoring encounters on college and university campuses, centered on gender match and race match of mentor-protégé pairings for resident assistants while controlling for confounding factors. However, there is much more to be learned 
about mentoring and leadership capacity. Ideally, more educators will conduct further research and more college students will engage in mentoring encounters. Findings from this research included mentoring as a positive predictor of leadership capacity, and through mentorship resident assistants are equipped with the abilities and confidence levels to create change.

In the Social Change Model, the outcome variable is change. Civically engaged leaders, like resident assistants, can leave a lasting impact long after they graduate. These students have the potential to transform their communities and society by strategically creating positive, purposeful, and sustainable change. Bainton (2006) shared a useful analogy on transformational leaders by discussing the impact of boiling water on a carrot, an egg, and a coffee bean. When a carrot is boiled, it becomes soft. When an egg is boiled, the shell becomes hard. However, when a coffee bean is boiled, the bean transforms the water. When resident assistants-regardless of gender/race mentor pairings, engage in mentoring relationships, they have an increased aptitude to serve as change agents and transform their environments and communities for the better. 


\section{References}

Astin, A.W. (1991). Assessment for excellence: The philosophy and practice of assessment and evaluation in higher education (pp. ix-xiv, 1-93). New York, NY: American Council on Education/Macmillan.

Astin, A. W. (1993). What matters in college: Four critical years revisited. San Francisco, CA: Jossey-Bass.

Astin, A. W., \& Astin, H. S. (2000). Leadership reconsidered: Engaging higher education in social change. Battle Creek, MI: W. K. Kellogg Foundation.

Bainton, D. (2006, March). Navigating academic politics: Women in leadership. Workshop at Where There's a Woman There's a Way: The Path to Leadership in Higher Education Conference, Office for Women in Higher Education, American Council on Education.

Blimling, G. S., \& Miltenberger, L. (1984). The resident assistant: Working with college students in residence halls (2nd ed.). Dubuque, IA: Kendall-Hunt. San Francisco, CA.

Campbell, C. M., Smith, M., Dugan, J. P., \& Komives, S. R. (2012). Mentors and college student leadership outcomes: The importance of position and process. The Review of Higher Education, 35, 595-625. doi:10.1353/rhe.2012.0037

Cilente, K. (2009). Overview of the social change model of leadership. In S. R. Komives \& W. Wagner (Eds.), Leadership for a better world: Understanding the social change model of leadership development (pp. 43-77). San Francisco, CA: Jossey-Bass.

Coe, R. (2002, September). It's the effect size, stupid: What effect size is and why it is important. Paper presented at the British Educational Research Association Conference, University of Exeter, England. Retrieved from http://www.cemcentre.org/Documents/CEM\%20Extra/EBE/ESguide.pdf

Cohen, J. (1988). Statistical power analysis for the behavioral sciences (2nd ed.). Hillsdale, NJ: Lawrence Erlbaum Associates.

Dugan, J. P. (2006). Involvement and leadership: A descriptive analysis of socially responsible leadership. Journal of College Student Development, 47(3), 335-343. doi: $10.1353 / \operatorname{csd} .2006 .0028$

Dugan, J. P. (2011). Research on college student leadership development. In S. R. Komives, J.P. Dugan, J. E. Owen, C. Slack, W. Wagner, \& Associates (Eds.), The handbook for student leadership development (2nd ed., pp. 59-84). A Publication of the National Clearinghouse for Leadership Programs. San Francisco, CA: Jossey-Bass. 
Dugan, J. P., Kodama, C. M., \& Gebhardt, M. C. (2012). Race and leadership development among college students: The additive value of collective racial esteem. Journal of Diversity in Higher Education, 5(3), 174-189. doi: 10.1037/a0029133

Dugan, J. P., \& Komives, S. R. (2010). Influences on college students' capacities for socially responsible leadership. Journal of College Student Development, 51, 525-549. doi: $10.1353 /$ csd.2010.0009

Author, (2014). An Examination of Mentoring Relationships and Leadership Capacity in Resident Assistants. (Doctoral dissertation). Retrieved from

Ender, S. C. (1984). Student paraprofessionals within student affairs: The state of the art. In S. C. Ender \& R. B. Winston, Jr. (Eds.), Students as paraprofessional staff (New Directions for Student Services, No. 27, pp. 3-21). San Francisco, CA: Jossey-Bass.

Ensher, E. A., \& Murphy, S. E. (1997). Effects of race, gender, perceived similarity, and contact on mentor relationships. Journal of Vocational Behavior, 50(3), 460-481. doi: 10.1006/jvbe.1996.1547

Higher Education Research Institute. (1996). A social change model of leadership development: Guidebook version III. College Park, MD: National Clearinghouse for Leadership Programs.

Kennedy, D. F. (2009). Exploring how resident advisors create meaning of their paraprofessional fall training and its transfer: A constructivist case study. (Doctoral dissertation). Retrieved from ProQuest Dissertations and Theses database. (UMI No. 3359124)

Komives, S. R. (1991). The relationship of same- and cross-gender work pairs to staff performance and supervisor leadership in residence life. Sex Roles, 24(5/6), 355-363. doi: 10.1007/BF00288308

Komives, S. R., Lucas, N., \& McMahon, T. R. (2007). Exploring leadership: For college students who want to make a difference (2nd ed.). San Francisco, CA: Jossey-Bass.

Kram, K. E. (1983). Phases of the mentor relationship. Academy of Management Journal, 26,

Northouse, P. G. (2010). Leadership: Theory and practice (5th ed.). Thousand Oaks, CA: Sage. 608-625.

Pascarella, E. T., \& Terenzini, P. T. (2005). How college affects students: Vol. 2. San Francisco, CA: Jossey-Bass.

Ragins, B. R. (1997). Diversified mentoring relationships in organizations: A power perspective. Academy of Management Review, 22, 482-521. 
Skendall, K. C. (2012). Socially responsible leadership: The role of participation in short-term service immersion programs (Doctoral dissertation). Retrieved from ProQuest Dissertations and Theses database. (UMI No. 3543488)

Swap, W., Leonard, D., Shields, M., \& Abrams, L. (2001). Using mentoring and storytelling to transfer knowledge in the workplace. Journal of Management Information Systems, 18, 95-114.

Tyree, T. M. (1998). Designing an instrument to measure socially responsible leadership using the social change model of leadership development (Doctoral dissertation). Retrieved from ProQuest Dissertations and Theses database. (UMI No. 9836493)

Winston, R. B. Jr., \& Fitch, R. T. (1993). Paraprofessional staffing. In R. B. Winston Jr., S. Anchors \& Associates (Eds.), Student housing and residential life: A handbook for professionals committed to student development goals. (pp. 315-343). San Francisco, CA: Jossey-Bass.

Winston, R. B., Jr., Ullom, M. S., \& Werring, C. J. (1984). Student paraprofessionals in residence halls. In S. C. Ender \& R. B. Winston, Jr. (Eds.), Students as paraprofessional staff (New Directions for Student Services, No. 27, pp. 51-66). San Francisco, CA: Jossey-Bass.

Young, A.M., Cady, S., \& Foxon, M. J. (2006). Demystifying gender differences in mentoring: Theoretical perspectives and challenges for future research on gender and mentoring. Human Resource Development Review, 5(2), 148-175.doi: 10.1177/1534484306287140 